\title{
Ernesto da Silva (1868-1903) y la biografía de líderes obreros en Portugal
}

\author{
Ernesto da Silva (1868-1903) and the Biography of Labor Leaders in Portugal
}

\author{
BEATRIZ PERALTA GARCÍA \\ Universidad de Oviedo \\ https://orcid.org/0000-0001-8232-7493 \\ bperalta@uniovi.es
}

\begin{abstract}
RESUMEN
Los líderes obreros han recibido, en general, muy poca atención por parte de los historiadores, que se han ocupado más de estudiar las organizaciones obreras (surgimiento, desarrollo, implantación entre las masas de asalariados, etc), o su papel en la historia política contemporánea. Con excepción de sus líderes más conocidos, que protagonizan sus fuentes, biografíar a otros menos celebrados es una cuestión de alguna dificultad para el historiador, que debe resolver imaginativamente su mayor problema: la falta de reflejo en las fuentes habituales, tales como la prensa, actas de reuniones, opúsculos, panfletos, textos programáticos..., etc. Este artículo se acerca sobre todo a la biografía de los líderes socialistas del siglo XIX a través de la pervivencia de su memoria en los militantes socialistas coetáneos, hasta alcanzar a los historiadores profesionales.
\end{abstract}

Palabras clave: Socialismo, Partido Socialista Portugués, líderes obreros, biografía, Portugal.

\section{Abstract}

Labor leaders have generally received very little attention from historians, who have been more concerned with studying workers' organizations (emergence, development, implantation among the masses of wage-earners, etc.), or their role in political history contemporary. With the exception of its best-known leaders, who star in its sources, the biography of others less celebrated is a matter of some difficulty for the historian, who must imaginatively solve his biggest problem: the lack of reflection in the usual sources, such as the press, meeting minutes, booklets, pamphlets, program texts ..., etc. This article is especially close to the biography of the socialist leaders of the 19th century through the survival of their memory in contemporary socialist militants, until reaching professional historians.

Palabras clave: socialism, Portuguese Socialist Party, labor leaders, biography, Portugal. 
"Em todo o caso a Revista continua. As inovações que se lhe fazem consistirão em a tornar mais congénere e adequada à mediocridade do Público — que se não interessa por alta literatura, e quer contos, viagens, biografias, etc". Eça de Queiroz, Correspondência.

"Os homens que, sempre revestidos d'uma modestia natural, seguem a estrada recta do dever, sem se deixarem perder pelas encruzilhadas onde a dignidade sossobra, não têem biographia".

J. Fernandes Alves, Antonio Joaquim da Conceição Pires.

“(...) a vida dos trabalhadores, no plano individual e colectivo tem sido descrita por grandes sociólogos, principalmente a partir dos meados do século XIX (...), mas o certo é nenhum deles ser procedente da classe operária". José Silva, Memórias de um operário.

\section{INTRODUCCIÓN}

A principios de abril de 1890 el novelista portugués José Maria Eça de Queiroz $(1845-1900)^{1}$ se encontraba en Oporto resolviendo asuntos familiares y personales. Para ello debió abandonar, durante algunos meses, sus responsabilidades como cónsul de Portugal en París, cargo que ejercía desde 1888. Entre los primeros, la herencia de su esposa, Emília de Castro, hija de la condesa de Resende, recientemente fallecida; entre los segundos, dinamizar la publicación que dirigía, Revista de Portugal, que atravesaba por algunas dificultades económicas. La solución parecía pasar por abrirla a un público más vasto con el ánimo de ganar suscriptores, lo que suponía adaptarla a un gusto que Eça calificaba de "mal educado e superficial", según le explicaba a su esposa en una carta escrita pocos días después de instalarse en la ciudad. Y concluía: "É o que naturalmente se fará"”. Unos días más tarde, le anunciaba la reestructuración que la publicación había sufrido, tanto a nivel directivo como en los contenidos, que se habían aligerado abandonando la llamada "alta literatura”, esto es, artículos de análisis, ya fuese histórico, literario, económico, político, artístico, etc., privilegiando géneros considerados menores: el cuento, frente a la que era conceptuada como su "hermana mayor", la novela; los relatos de viajes, y las biografías. "Nada do que ele (el pueblo) gosta lhe recusaremos a não ser a charada", escribió, es decir, se negaba a publicar cualquier texto que supusiese un mero entretenimiento lúdico.

Sirva esta pequeña pero esclarecedora anécdota para valorar el desprestigio del género biográfico a finales del Ochocientos a través de un intelectual de prestigio. Género superficial, carente de análisis, popular, no fue objeto de interés en décadas posteriores hasta el punto de que casi un siglo después del lamento de Eça, el profesor Antonio Mo-

1 Autor, por ejemplo, de obras como O primo Basílio (1878), O crime do padre Amaro (1880), Os Maias (1888), y A ilustre casa de Ramires (1897), entre otras.

2 Queiroz, Eça de, “425. A Emília de Castro”, Correspondência. Volume II, organização e anotações de A. Campos Matos, s.1., Caminho, 2008, p. 32. La carta está fechada en Oporto, el día 22 de marzo de 1890.

3 Queiroz, Eça de, “421. A Emília de Castro”, ídem, p. 40. 
rales Moya fijaba entre el final de la II ${ }^{\mathrm{a}}$ Guerra Mundial y los años 80 del siglo XX el agotamiento histórico-literario de la biografía ${ }^{4}$. Frente a lo que pudiera pensarse teniendo en cuenta las quejas del célebre novelista portugués, hasta al menos el siglo XVIII la biografía era muy estimada, porque las vidas de personajes ilustres tenían un carácter político, lo que las convertía en narraciones muy apreciadas por su cercanía con los tratados de Filosofía Política ${ }^{5}$. No trataremos de abordar una "historia o biografía" de la misma biografía, sino antes constatar el posterior cambio de tendencia desde las décadas finales del siglo XX y hasta la actualidad, como ya el profesor Morales Moya notaba en su artículo, lo que hace de ella un género atractivo tanto para los historiadores como para el público en general -en esto último, al menos, no se observa cambio de tendencia. Esta afirmación contiene, además, dos nociones consensuales, a saber: que se trata de un género historiográfico específico, y también que en la medida que interesa al público contiene algunas características particulares que la vinculan con la literatura. En general, como señala la profesora Maria de Fátima Bonifácio, subyace la idea de que un relato biográfíco debe presentar un enredo, una trama, una intriga dramática que permita la reconstrucción histórica destacando la figura del personaje como elemento dominador, aspecto este que lo hace entroncar con otras estructuras narrativas, como la autobiografía y los libros de memorias ${ }^{6}$. Además, en la medida en que favorece la reconstitución de determinada época o período en el que el personaje histórico habría tenido una presencia destacable o, incluso, determinante, estaremos en presencia de una biografía "política", como subraya la historiadora antes citada, de la que quedarían fuera figuras menores, de personajes anónimos, que no serían sino ejemplos de una colectividad. Transitaríamos por lo tanto, de la histórica política a la historia social. Así, aplicadas estas consideraciones al estudio del movimiento obrero, se imponen algunas preguntas: ¿dónde se situaría la biografía de sus líderes? ¿Hasta qué punto socialistas tan conocidos para los investigadores como José Fontana o Azedo Gneco, y otros menos destacados, como Ernesto da Silva, todos muy populares en los medios obreros de finales del siglo XIX pero tal vez desconocidos entre los principales agentes de la política partidaria de la época, pueden ser protagonistas de una "historia política" o, incluso, de una "historia social", según el caso? Parece imponerse un cambio de perspectiva. Se trataría no tanto de escoger a una figura relevante por su capacidad para influir en el devenir histórico, sino de estudiar hasta qué punto estos líderes obreros, o su liderazgo dentro de las organizaciones obreras, influyeron en ese devenir histórico. A estos interrogantes se añade otro, este de carácter puramente técnico, pues ¿cómo proceder a la reconstrucción biográfica de un líder y de

4 Morales Moya, Antonio, "Biografía y narración en la Historiografía actual”, en Sánchez Nistal, José María, y otros, Problemas actuales de la Historia. $3^{\text {as }}$ Jornadas de Estudios Históricos, Salamanca, Universidad de Salamanca, 1993, p. 229.

5 Alférez Sánchez, María, "La Vida de Quevedo de Pablo de Tarsia: un modelo excepcional en la producción biográfica del Siglo de Oro", Revista de Historiografía, 30, 2019, pp. 225-244.

6 Bonifácio, Maria Fátima, "Biografia e conhecimento histórico", Estudos de história contemporânea de Portugal, Lisboa, ICS, 2007, p. 243. 
su época dadas las dificultades para seguir su rastro entre los vestigios documentales que nos han llegado? Lo dificultoso de la empresa no debería desanimar al historiador profesional, pues entendemos que biografiar a estas personalidades ofrece otra mirada dentro de la historia política y de la historia social, fundiendo ambas perspectivas, de suerte a crear un relato que contemple no solo rasgos propios de estas disciplinas sino que, necesariamente, debe incluir otros elementos. Entre ellos, el recurso a fuentes de análisis menos habituales, como las periodísticas y las literarias, ya que muchos de estos obreros fueron autores de una vasta producción narrativa, lírica y dramática, además de artículos periodísticos diversos, de consulta imprescindible. La biografía de estos líderes vendría a funcionar a un tiempo como género e instrumento de análisis, por lo que se hace necesario empezar por identificarlos a ellos y a su obra, ya que muchos permanecen, aún en la actualidad, en el anonimato.

\section{LOS FUNDADORES Y LA «TRIADA SALEMISTA». MEMORIA Y BIOGRAFÍA DE LÍDERES OBREROS EN PORTUGAL (1875-1910)}

Uno de los mayores hitos en la historia del movimiento obrero en Portugal fue la fundación en Lisboa del Centro Promotor dos Melhoramentos das Classes Laboriosas (1852-1873) al amparo del nuevo marco legislativo tras la llegada al poder de Fontes Pereira de Melo en el gobierno salido del golpe de Estado del duque de Saldanha (18511856), y su apuesta por el desarrollo de un capitalismo industrial basado en la inversión pública. El Centro Promotor nacía con la voluntad de evitar la conflictividad laboral fomentando el asociacionismo entre los trabajadores, y con una vocación interclasista que favorecía la convivencia de liberales progresistas, republicanos y socialistas, en general muy influidos por las doctrinas de Fourier y Saint-Simon. Ahí llegarían a recalar los escritores y periodistas António Pedro Lopes de Mendonça (1826-1865) y João Bonança (18361924), el ingeniero Francisco Maria de Sousa Brandão (1818-1892), el tipógrafo Francisco Vieira da Silva (1825-1868). o el grabador Eudóxio César Azedo Gneco (1849-1911), futuro dirigente del Partido Socialista Portugués. Hacia mediados de los años 60 la realización en su sede de un Congreso Social (1865) que debatió los límites y características que debía tener el asociacionismo en Portugal, mostró la existencia de una nueva sensibilidad hacia el mundo del trabajo entre los socios que florecerá pocos años después. A principios de la nueva década surgirá una generación de jóvenes muy influidos por las ideas de la AIT y la reciente experiencia de la Comuna de París, entre ellos, Antero de Quental (18421891), miembro del grupo literario "generación de 70” al que también pertencía el escritor Eça de Queiroz, antes referido7 , y el tipógrafo José Fontana (1840-1876). En comunión con las actividades propagandísticas desarrolladas habitualmente dentro de la institución

7 Sobre la historia del Partido Socialista Portugués, vid. Peralta García, Beatriz, "El Partido Socialista Portugués y la literatura de combate. La obra literaria de Ernesto da Silva", Revista Historia Autónoma, 11, 
organizarán, en mayo de 1871, las célebres Conferências do Casino Lisbonense, que tanto alarmaron al marqués de Ávila, a la sazón presidente del Consejo de Ministros, motivo por el que decretó su prohibición inmediata. Argumentaba el despacho ministerial que ahí se exponían, y sostenían, doctrinas y proposiciones que atacaban a la religión y a las instituciones políticas del Estado. Entendía, además, que constituían un "abuso" del derecho de reunión, y una "ofensa" a las leyes del reino y al "código fundamental da monarquia". Tales "doctrinas y proposiciones" eran la apuesta de algunos miembros del Centro Promotor para orientarlo hacia un socialismo más reivindicativo, lo que generó una fuerte tensión interna. El punto de inflexión se produjo con la ingerencia del Ministro do Reino y antiguo socio António Rodrigues Sampaio en los asuntos del Centro Promotor, al negarse a amparar en él discusiones políticas. A finales de ese año Fontana y sus seguidores -Eduardo Maia (1845-1897), José Correia Nobre França (1838-1920) y Sousa Brandão- se harán con el control del Centro Promotor, aunque la pretensión de reconducirlo hacia una organización socialista de corte internacionalista fracasó ${ }^{9}$. A partir de este momento lo abandonan definitivamente para comenzar a organizar el movimiento socialista, que se tradujo en la aparición de varias agrupaciones: la dirigida por Nobre França; la vinculada al conde de Peniche; y la de José Fontana, denominada Associação Protectora do Trabalho Nacional. Este grupo, junto a la Sociedade dos Artistas Lisbonenses, dará lugar a Fraternidade Operária (1871) — considerada la primera asociación obrera con alguna entidad que hubo en el país-, para la que Antero escribiría el opúsculo O que é a Internacional? A pesar de algunas vacilaciones iniciales para adherirse formalmente a esta organización —entendía que solo la revolución política podía llevar a la transformación económica, en franca oposición con Nobre França, que entendía exactamente lo contrario-, acabaría por hacerlo el 10 de marzo de 1872, poco antes de la llegada de Paul Lafargue a Lisboa buscando el apoyo de los internacionalistas portugueses para el congreso de La Haya. Estos verían en la propuesta de Lafargue la oportunidad para hacerse representar en él, según le relataba Nobre França a Marx en una carta enviada en agosto de 1872. Tras este bautismo internacional siguieron años de lenta construcción organizativa con la creación de una agrupación orientada a la lucha política, opción a la que fueron inicialmente renuentes, pues solo lograría materializarse a partir de 1875 con la fundación del Partido Socialista Português ${ }^{10}$. Las disensiones internas llevaron años después a una escisión partidaria que se plasmó en

2017, pp. 114-124. Dentro de la historiografía portuguesa es de obligada lectura Mónica, Maria Filomena, O movimento socialista em Portugal (1875-1934), Lisboa, Imprensa Nacional-Casa da Moeda, 1985.

8 "Portaria do Reino de 26 de junho de 1871 proibindo futuras conferências", en Quental, Antero de, Causas da decadência dos povos peninsulares nos três últimos séculos, Lisboa, Tinta-da-China, 2008, p. 99.

9 Lázaro, João, “O Centro Promotor dos Melhoramentos das Classes Laboriosas. Integração e rutura na sociedade liberal portuguesa (1852-1873)”, Revista Portuguesa de História, t. L. (2019), pp. 67-85; Peralta García, Beatriz, "El Partido Socialista Portugués...”, op. cit., pp. 114-117.

10 La carta está fechada el día 23 de agosto de 1872. Vid. Oliveira, César de, 13 de cartas de Portugal para Engels e Marx. Recolha, prefácio e notas de César de Oliveira, Lisboa, Iniciativas Editoriais, s.d., p. 39; relato de los hechos en p. 61 y ss. 
dos agrupaciones diferentes: el Partido dos Operários Socialistas de Portugal (POSP, 1878), de carácter posibilista (o sindicalista), dirigido por Manuel Luiz de Figueiredo (1861-1927), y el Partido Socialista Português (PSP, 1892), la facción marxista o revolucionaria, de Azedo Gneco, de factura política. Estas tensiones en el seno del socialismo portugués no impedirían que a inicios de la década de los años 90 las ideas socialistas se consolidasen dentro del movimiento obrero nacional, momento en el que sus líderes locales comenzaron a individualizarse y a ganar protagonismo entre las masas de obreros asalariados, y ello a pesar de la creciente competencia con los anarquistas ${ }^{11}$. Dos elementos jugaron a su favor: el desarrollo de su prensa, que desde la fundación del PSP y hasta la institucionalización del Estado Novo (1933-1974) vio aparecer cabeceras como O Protesto (Lisboa, 1875-1882), O Operário (Lisboa, 1879-1882), O Protesto Operário (Lisboa, 1882-1894), Eco Socialista (Oporto, 1892-1894, 1899, 1900-1901), A Federação (Lisboa, 1893-1900), Revolucionário (Lisboa, 1893, 1896, 1902), O Trabalhador (Oporto, 18961897), A Lucta (Lisboa, 1900), O Primeiro de Maio (Lisboa, 1903-1907), A República Social (1908-1909), O Socialista (Lisboa, 1912-1913), O Combate (Lisboa, 1914-1919), O Socialista (Lisboa, 1919-1920), República Social (Oporto, 1919-1920; 1921-1930), у O Protesto (Lisboa, 1922-1926; 1931-1934); y la formalización del calendario festivo obrero, que incluía al menos tres fechas importantes: la fundación del PSP, el día 10 de enero de 1875; la conmemoración de la Comuna (18 de marzo); y el $1^{\circ}$ de mayo a partir de 1890 , además de las fiestas benéficas, que carecían de periodicidad fija. Ambos elementos, prensa y festividades obreras, actuarían conjuntamente como elementos singulizadores de los líderes obreros, al servir las segundas como pretexto para su publicidad a través de la primera, uno de los principales canales de difusión doctrinaria. Sus promotores fueron, sobre todo, los integrantes del PSP frente al POSP, que desde su constitución como grupo se mostrarían mucho más activos en cuanto a la celebración de este tipo de efemérides, y por ello, especialmente proclives a incluir en los periódicos partidarios notas biográficas de los militantes portugueses y de los socialistas europeos en un número o en una sección conmemorativa, costumbre que mantuvieron tras la unificación partidaria de 1910. Encontramos en sus periódicos una de estas primitivas semblanzas, un pionero relato sobre la vida de Fontana que fue publicado con motivo del $1^{\circ}$ de mayo de 1892 en el órgano oficial del POSP, O Protesto Operário, a cargo de António Joaquim da Conceição Pires $(\dagger 1903)^{12}$. Ese mismo año vió la luz un Homenagem a José Fontana (Lisboa, Typ. do Reporter, 1892) ${ }^{13}$, aunque para disfrutar de una biografía completa de uno de los primeros líderes

11 La historiografía discrepa en cuanto a los años de expansión del anarquismo en Portugal. En términos generales, podríamos situar en la transición de la década de los años 80 a 90 los años de mayor implantación dentro del operariado portugués. Ventura, António, Anarquistas, republicanos e socialistas em Portugal. As convegências possíveis (1892-1910), Lisboa, Edições Cosmos, 2000, pp. 84-87.

12 “José Fontana", O Protesto Operario, Lisboa, 508, 1 de maio de 1892, p. 2.

13 Según informa el Arquivo de História Social, de la Universidade de Lisboa, que indica que el documento no se puede consultar. http://www.ahsocial.ics.ulisboa.pt/atom/homenagem-jose-fontana-lisboa-typ-doreporter-1892-bibliotheca-do-trabalhador 
socialistas portugueses habrá que esperar hasta 1898, cuando P. Carvalho la publique en $O$ Proletario. En ese mismo número también podía leerse un extenso relato de la vida de Marx, hasta ese momento algo poco habitual en la prensa partidaria ${ }^{14}$. Cuando el periódico incluía secciones conmemorativas, la biografía completaba la noticia periodística protagonizada por alguna personalidad de renombre nacional ${ }^{15} \mathrm{o}$ internacional, como el aniversario de la muerte de Marx (14 de marzo de 1883), que coincidía en cercanía con la fiesta de la Comuna ${ }^{16}$. El segundo aniversario de la muerte de Azedo Gneco en 1913, por ejemplo, llevó a los socialistas de diferentes organismos partidarios hasta su tumba en el cementerio de los Prazeres, en Lisboa. Allí, Manuel do Carmo Barão (1876-1918) en nombre del Conselho Central del PSP, António Maria Abrantes en el de la Federação Municipal Socialista, João Graça en el de la Federação Operária, y António Marques en el del Centro Socialista de Lisboa, glosaron su figura como luchador a favor de la clase obrera y del proletariado portugués ${ }^{17}$.

Pero además de su celebración en la prensa, estas festividades comportaban la organización de un conjunto de actos en alguno de los centros socialistas, en el caso de Lisboa, sobre todo en el Centro Socialista de Lisboa o en el Centro Socialista Occidental, cuya divulgación en la prensa también favorecía la aparición de biografías. Igualmente la celebración de la fundación del Partido y, sobre todo, la conmemoración del $1^{\circ}$ de mayo, tuvieron desde sus inicios un marcado sentido lúdico y reivindicativo, pero también una dimensión "tanatológica", en palabras del profesor Fernando Catroga ${ }^{18}$, que llevaba a los socialistas en romería a los cementerios para honrar a los compañeros fallecidos ${ }^{19}$, como sucedía en Lisboa con José Fontana. Así lo hicieron los miembros del PSP en 1895 antes incluso de su constitución oficial como agrupación partidaria en Tomar en octubre de ese año al organizar un mítin ante su sepultura ${ }^{20}$. Un año más tarde, la conmemoración del

14 "José Fontana", O Proletario. Bi-semanario defensor do operariado em geral, Lisboa, 1, 1 de maio de 1898, p. 2, y "Karl Marx", ídem, p. 3.

15 En 1897 el periódico A Obra publicó una biografía del abogado y escritor Manuel Veloso Armelim Junior. Lucena, Raul de, "Dr. Armelim Junior", A Obra. Órgão dos Carpinteiros Civis Associados, Lisboa, 114, 21 de março de 1897, pp. 1-2.

16 "Karl Marx”, O Protesto Operario. Órgão do Partido Operario Socialista, 543, 19 de março de 1893, p. 1, que incluía un retrato; "Carlos Marx", A Federação. Órgão das Associações Federadas e do povo operario em geral, Lisboa, 64, 24 de março de 1895, p. 2. Otras veces se incluía una breve nota: "Karl Marx", O Echo Metallurgico. Órgão da confederação das Associações de Classe Metallurgicas de Lisboa e do povo em geral, Lisboa, 20, 15 de março de 1896, p. 2; "Karl Marx”, A Federação, Lisboa, 115, 15 de março de 1896, p. 1.

17 “Azedo Gneco", O Socialista, 349, 29 de junho de 1913, p. 1; y "Manifestação a Azedo Gneco", ídem, 350, 30 de junho de 1913, p. 2.

18 Catroga, Fernando, "Os primórdios do 1. e maio em Portugal. Festa, luto, luta”, Revista de História das Ideias, 11, 1989, p. 446 y ss.

19 "Dionysio Sampaio", O Protesto Operario, Lisboa, 455, 1 de março de 1891, p. 3. El tipógrafo Dionísio Sampaio murió prematuramente. Una de sus obras, O Rouget de Lisle, un poema dramático, le sirvió de inspiración a Ernesto da Silva para escribir un drama de denuncia social, O Capital.

20 Vid., por ejemplo, la celebración del $1^{\circ}$ de mayo de 1895. "O 1. ' de Maio", A Vanguarda, Lisboa, 1390, 2 de maio de 1895 , p. 2. 
$1^{\circ}$ de mayo de 1896 fue especialmente pródiga en cuanto a la difusión biográfica de los líderes socialistas portugueses, ya que Azedo Gneco haría de esta celebración una de las señas de identidadad del PSP frente al POSP. Por eso, A Federação, el periódico de la Federação das Associações de Classe — agrupación sindical vinculada al PSP_, que él mismo dirigía, incluyó una amplia biografía suya, de la autoría de otro dirigente histórico del Partido, António Henrique Soto Maior Júdice (1834-1903), que acompañó de un dibujo del protagonista ${ }^{21}$. Este autor fue a su vez biografíado en el republicano A Vanguarda, junto a Gneco y Ernesto da Silva (1868-1903)22. En 1897 el periódico O Tecido, el órgano de la Associação de Classe dos Manufactores de Tecidos, publicaba una biografía de Azedo Gneco firmada por Judice Bicker en la portada de su número dedicado al $1^{\circ}$ de mayo, acompañada de su retrato ${ }^{23}$.

Fuera de los periódicos y de las celebraciones partidarias, le debemos a Ernesto da Silva, compositor tipógrafo de la Imprensa Nacional y militante socialista desde 1892, primero del POSP y después del PSP, ser uno de los precursores de la difusión en Portugal de la obra de varios líderes vinculados al movimiento obrero, como José Fontana y Sousa Brandão, y el socialista utópico británico Robert Owen. En 1892 acudió como representante de la Federação das Associações de Classe a la celebración del vigésimo aniversario de la creación de la Cooperativa Industria Social, donde se iba a rendir homenaje a José Fontana como fundador del PSP, y al ingeniero Sousa Brandão como defensor del asociacionismo. El texto que escribió, titulado Fontana e Sousa Brandão, no es una biografía al uso, sino una reflexión entorno a las condiciones laborales y de vida de los obreros portugueses en la segunda mitad del siglo XIX y su organización en asociaciones de todo tipo: partidarias, sindicales, cooperativistas..., para la mejor defensa de sus intereses de clase. Ernesto da Silva realiza un análisis clásico sobre la miseria del proletariado industrial, reconociéndo a ambos líderes como propagandistas incansables y altruistas en defensa de un ideal, que actuaron en un medio socioeconómico y cultural injusto. Su análisis incide en la forma en la que, según él, las élites enfrentaban el desequilibrio social: por un lado, negándolo o dulcificándolo; y por otro, oponiendo la filosofía del pensamiento a su acción práctica, señalando lo dispar de ambas. En este contexto se inscribía, para Ernesto da Silva, la intervención de Fontana y Sousa Brandão a favor del operariado portugués, destinada a ayudar a los obreros a organizarse con el objetivo de promover la transformación de la sociedad ${ }^{24}$.

21 Sotto Maior Judice, “Azedo Gnecco”, A Federação, Lisboa, 122, Primeiro de Maio de 1896, pp. 1-2.

22 A Vanguarda, Lisboa, 1751, 1 de maio de 1896, p. 1.

23 Bicker, Judice, "Uma biographia", O Tecido. Órgão da União das Classes Textis em Portugal, 61, 1 de maio de 1897, pp. 1-2.

24 Silva, Ernesto da, Fontana e Sousa Brandão. Discurso pronunciado na sessão commemorativa do $20{ }^{\circ}$ anniversario da Cooperativa Industria Social, Lisboa, Typ. do Instituto Geral das Artes Graphicas, 1893. La figura de Sousa Brandão cayó a partir de entonces en un cierto olvido. En 1897 el periódico O Echo Metallurgico le dedicó una breve semblanza con motivo del $1^{\circ}$ de mayo de ese año. "Sousa Brandão", $O$ Echo Metallurgico, Lisboa, 70, 1 de maio de 1897, p. 3. 
Algunos años más tarde, y ya fuera de las estructuras partidarias ${ }^{25}$, Ernesto da Silva fue invitado por la cooperativa A Libertadora para hablar sobre Robert Owen. A pesar de no ser "essencialmente cooperativista", como explicó a los oyentes, y de lo "pesado", y hasta "temerário" de la empresa, decidió aceptar la propuesta con "o intuito de prestar modesto preito á memoria d'um grande homem, que foi um potente luctador a bem dos opprimidos. Tanto basta a que cumpra um dever sagrado", afirmó, seguro de que "a boa vontade vae supprir a defficiencia de rapido estudo, feito na evocação das intenções de Owen ao lançar os fundamentos da idéa cooperativista" ${ }^{26}$. En efecto, de nuevo Ernesto da Silva aprovechó el acto para glosar la figura de Robert Owen y la del resto de los socialistas utópicos, Fourier y Saint-Simon, haciéndolos entroncar con la filosofía de Benoît Malon tal y como este autor la exponía en Le socialisme integral (1891). En su texto, Ernesto da Silva señalaba algunas perversiones originadas al intentar poner en práctica las innovaciones socioeconómicas defendidas por Owen: de un lado, el hecho, triste y paradójico, de que los hombres, habituados a la esclavitud, no supieron apreciarlas y por ello reclamaron mantenerse en el sistema opresivo en el que vivían, una respuesta humana ya notada por Rousseau en el Contrato Social; y por otro, que el sistema cooperativista pasó de ser un fin a transformarse en un simple medio, lo que significó la obtención de lucros destinados al enriquecimiento de una minoría. El texto fue publicado bajo el título Elogio histórico de Roberto Owen, en el periódico A Obra, el órgano de la Associação de Classe dos Carpinteiros Civis. Sería la primera vez que los obreros asistentes al acto se enfrentasen a la divulgación de la vida y la obra de uno de los representantes del llamado "socialismo utópico", un acto único que no tuvo continuidad en el tiempo, pues hasta 1941 no encontraremos en Portugal una biografía de Owen, Vida de Robert Owen, del profesor Agostinho da Silva. Uno de sus textos más conocidos, Uma nova concepção da sociedade, no será traducido y anotado hasta 1976, ya finalizada la dictadura salazarista, por Luísa Leal de Faria, ya que la divulgación de la biografía de los líderes obreros europeos y de sus obras en la sociedad portuguesa se hizo de forma tardía, pues las traducciones al portugués solo se generalizaron a lo largo del siglo XX. Solo una minoría culta de obreros intelectualizados podía acceder a ellas, principalmente a partir de ediciones en francés, por lo que los socialistas portugueses favorecieron la traducción de estos textos como una más de las estrategias de divulgación de las ideas socialistas en Portugal. Entre los autores más difundidos hasta el final de la centuria hay que citar a Benoît Malon, Paul Lafargue — ambos por el Grupo de Propaganda Socialista vinculado al PSP y del que formaba parte Ernesto da Silva-, y en menor medida, a Jean Grave.

25 Abandonó el PSP en junio de 1897. Peralta García, Beatriz, “Aproximación a la vida y a la obra de Ernesto da Silva", Historia Social, nº 89, 2017, p. 63.

26 Silva, Ernesto da, "Elogio Historico de Roberto Owen. (Lido em sessão solemne da cooperativa A Libertadora em 19 de março de 1898)", A Obra, Lisboa, 166, 20 de março de 1898, p. 3. 


\section{HACIA EL OLVIDO DEL SOCIALISMO PORTUGUÉS DECIMONÓNICO (1910-1933)}

Ernesto da Silva era, como podemos intuir por lo expuesto anteriormente, un líder obrero de reconocido prestigio en la última década del siglo XIX. Su prematuro fallecimiento en Lisboa con apenas treinta y cinco años de edad, solo unos días antes de la celebración del $1^{\circ}$ de mayo de 1903, provocó un enorme impacto emocional y motivó a algunos periódicos a dedicarle sus números conmemorativos con motivo de esta fecha, como el republicano $O$ Mundo, en el que colaboraba en el momento de su muerte ${ }^{27}$; o A Obra, que había dirigido entre 1897 y 1898, incluyendo una biografía realizada por uno de sus amigos, Heliodoro Salgado ${ }^{28}$. Además, su círculo de amistades promovió un reconocimiento a su labor como propagandista del socialismo publicando un periódico en su honor, Justiça. Homenagem a Ernesto da Silva, con colaboraciones que analizaban su figura y su obra literária, especialmente su faceta de dramaturgo, por la que era especialmente admirado $^{29}$, y donde destaca una poesía de encomio que completa un conjunto lírico surgido a raiz de la representación de su drama más aplaudido, O Capital (1895). No sería la última vez que se prestase homenaje a su memoria, pues los tributos a su vida y a su obra se prolongaron entre los socialistas en años sucesivos. Uno de los actos más importantes de la conmemoración del $1^{\circ}$ de mayo de 1908 fue el traslado de sus restos mortales $^{30}$.

La de Ernesto da Silva fue, tal vez, la primera de las numerosas pérdidas de líderes obreros que el socialismo portugués sufriría desde inicios del s. XX y en los años posteriores a la proclamación de la República. En el plano organizativo interno, y aunque alejado del PSP por sus fuertes desavenencias con Azedo Gneco, no pudo ser testigo de la ansiada unión partidaria, lograda después de algunas dificultades el 23 de abril de 1910, cumpliendo con el mandato del Congreso Internacional de Amsterdam de 1907, que decretó la existencia de un único partido socialista como estrategia de lucha contra la burguesía. El socialismo portugués llegó, pues, providencialmente unido a la proclamación de la República, apenas unos meses más tarde, el 5 de octubre. Con el nuevo régimen la celebración de las efemérides socialistas se mantuvo e, incluso, se acentuó, ahondando en el culto a la memoria de los líderes desaparecidos. Tras el agitado período de finales de 1910 a 1912, marcado por una oleada de huelgas en el campo y en la industria, la Federação Municipal Socialista de Lisboa fue la encargada de organizar a partir de 1913

27 "Ernesto da Silva", O Mundo, Lisboa, 937, 26 de abril de 1903, p. 1.

28 Vid. Salgado, Heliodoro, "Ernesto da Silva. A sua acção", A Obra, Lisboa, 430, 1 de maio de 1903, p. 1, y en general todo el número, a él dedicado.

29 Justiça. Homenagem a Ernesto da Silva, Lisboa, número único, $1^{\circ}$ de maio de 1903.

30 A Voz do Operario, 1489, 10 de maio de 1908, p. 3, apud. Catroga, Fernando, "Os primórdios do $1 .^{\circ}$ de maio...", op. cit., p. 471. 
las romerías al cementerio con motivo del $1^{\circ}$ de mayo ${ }^{31}$, que en $1915^{32}$ y $1917^{33}$ fueron de homenaje conjunto a Fontana y Azedo Gneco, entre tanto fallecido en 1911. En 1916 las fuentes incluyen el dato de que la celebración comprendía una visita al túmulo de Ernesto da Silva ${ }^{34}$. Pero a inicios de la década de los años 20 la memoria de estos líderes empezaba a apagarse y apenas se mantenía en el recuerdo de quienes los habían conocido, como Ladislau Batalha (1856-1939), miembro del PSP y autor, junto a Ernesto da Silva, de un texto conjunto que publicaron con motivo del $1^{\circ}$ de mayo de $1896^{35}$; o de José Martins Santareno, el encargado de redactar para $O$ Protesto, de Lisboa, que él dirigía, la necrológica de otro socialista histórico, Teodoro Ribeiro, fallecido en 1922, que había acompañado a Gneco y a Ernesto da Silva en la constitución del PSP, donde lo recordaba como integrante de lo que él denominó "la tríada de los salemistas", esto es, Gneco, Ernesto da Silva y Teodoro Ribeiro ${ }^{36}$. Tal vez debido al tiempo transcurrido, o porque la ofrenda floral por la festividad del $1^{\circ}$ de mayo de 1923 fuese especialmente dedicada a Fontana y Azedo Gneco, con participación de varios oradores en el cementerio de los Prazeres ${ }^{37}$, el intelectual republicano Mayer Garção (1872-1930) sintió que Ernesto da Silva, uno de sus mejores amigos, estaba siendo lentamente olvidado. Lo incluyó entre Os esquecidos (Los olvidados), una obra dedicada al reconocimiento de personalidades diversas que publicó en 1924, aunque esta negativa percepción no parece afectar a los socialistas, ya que el programa de actos conmemorativo del $1^{\circ}$ de mayo de ese año incluyó el traslado de los restos mortales de Ernesto da Silva al osario 714 del cementerio de los Prazeres, además del homenaje junto a Fontana, Gneco y Teodoro Ribeiro ${ }^{38}$. Simultáneamente, los socialistas de Benfica inauguraron ese año el Largo Ernesto da Silva con motivo de esta festividad $^{39}$. En el $1^{\text {o }}$ de mayo de 1925 los socialistas acudieron de nuevo a las tumbas de Fontana, Gneco, Ernesto da Silva y Teodoro Ribeiro, según noticiaba O Protesto ${ }^{40}$. En julio, el periódico, dirigido desde finales de mayo por Martins Santareno, le dedicaba a Azedo Gneco un número conmemorativo ${ }^{41}$.

31 "Federação Municipal Socialista de Lisboa", A Batalha Socialista, Lisboa, 3, 1 de maio de 1913, p. 1.

32 "Homenagem a José Fontana e Azedo Gnecco", O Combate, Lisboa, 36, 1 de maio de 1915, p. 2; "Federação Municipal Socialista de Lisboa", Avante, Lisboa, 5, 30 de abril de 1915, p. 2.

33 "1 de maio. A festa da Amadora", O Combate, Lisboa, 132, 13 de maio de 1917, p. 1.

34 "Reuniões e Comemorações. Federação Municipal Socialista”, O Combate, Lisboa, 82, 30 de abril de 1916, p. 1.

35 Batalha, Ladislau, y, Silva, Ernesto da, O que é ser socialista? O dia normal, Lisboa, Lisboa, Typ. do Instituto Geral das Artes Graphicas, s.d.

36 Santareno, Martins, "Teodoro Ribeiro", O Protesto, Lisboa, 22, 26 de novembro de 1922, p. 1.

37 “Comissão Socialista de Arroios", O Protesto, Lisboa, 41, 1 de maio de 1923, p. 2. "Salemistas" era la denominación de los miembros del PSP, que se reunían en el Pátio do Salema, en Lisboa.

38 Mayer Garção, Os esquecidos, Lisboa, Empresa Editora e de Publicidade A Peninsular Ld ${ }^{a}$., 1924, pp. 61-66; Salgado, Heliodoro, "Epitafio de Ernesto da Silva”, Benfica Socialista, Lisboa, 1, 1 de maio de

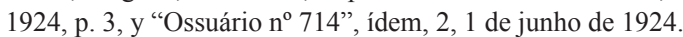

39 "Programa da comemoração do $1^{\circ}$ de maio", Benfica Socialista, Lisboa, 1, 1 de maio de 1924, p. 1.

40 “A manifestação do $1^{\circ}$ de Maio", O Protesto, Lisboa, 140, 10 de maio de 1925, p. 1.

41 O Protesto, Lisboa, 148, 5 de julho de 1925. 
Es a finales de esta década de los años 20 cuando parece recuperarse el nombre del otro fundador histórico del PSP, Antero de Quental. Su memoria era cultivada especialmente entre los socialistas de la isla de São Miguel, en el archipiélago de las Azores, que en 1916 denominaban con su nombre al Centro Socialista de Punta Delgada, su ciudad natal, y divulgaban su figura a través de sus poemas o los que le eran dedicados con motivo del aniversario de su fallecimiento, el 9 de noviembre de $1891^{42}$. Habrá que esperar hasta 1926, en vísperas del golpe de Estado que inició los años de la Dictadura Militar (1926-1933), para encontrar en O Protesto, órgano de los socialistas de Punta Delgada (São Miguel, Azores), un poema firmado por José de Almeida ofrecido a Antero de Quental $^{43}$. En 1928, República Social, de Oporto, les dedicaba a él y a José Fontana una sección titulada "Página Histórica" 4 . Otros líderes locales eran también celebrados, como los fundadores de la Liga da Mocidade Socialista do Porto, que protagonizaron la portada de su recién fundado órgano de expresión, O Neo-Socialista — aparecido significativamente en el aniversario del golpe de Estado republicano de 31 de enero de 1890_, entre ellos, el histórico Manuel José da Silva (1858-1932) y un joven Ramada Curto (1886-1961) ${ }^{45}$. En las localidades pequeñas se repetían estos mismos esquemas de celebración. En 1927, ya en plena Dictadura Militar, los socialistas de Covilhã tuvieron que desistir de celebrar la fiesta del $1^{\circ}$ de mayo en su Casa do Povo, pero el Centro Socialista organizó una sesión de propaganda y un espectáculo en el que su estudiantina se trasladó al cementerio para rendir homenaje a los compañeros fallecidos, entonando el himno del $1^{\circ}$ de mayo ${ }^{46}$.

\section{OLVIDO INSTITUCIONAL Y MEMORIA MILITANTE (1933-1974)}

La proclamación de la Constitución de 1933 institucionalizó en Portugal un régimen de carácter autoritario denominado Estado Novo al que el PSP no logró sobrevivir ${ }^{47}$. Los temores de Mayer Garção relativos al olvido de personalidades que tanto desde el lado socialista como del republicano marcaron la vida social de estos grupos en los años finales de la Monarquía y durante la República, se vieron confirmados en 1936, cuando con motivo de la inauguración solemne de dos lápidas evocativas de las individualidades

42 "Partido Socialista Portuguez. Centro Socialista Anthero de Quental", O Protesto, Ponta Delgada, 1, 16 de novembro de 1916, p. 4; "Gloria a Anthero de Quental", ídem, 25, 15 de novembro de 1917, p. 2.

43 Almeida, José de, "Maio do Futuro. (À memória de Antero de Quental)", O Protesto, Lisboa, 188, 1 de maio de 1926, p. 2.

44 "Página Histórica", República Social, Porto, 342 (2 ${ }^{\mathrm{a}}$ série), 1 de setembro de 1928, p. 3, dedicado a Fontana; y 343 ( $2^{\mathrm{a}}$ série), 8 de setembro de 1928, p. 3, dedicado a Antero de Quental, que incluía un poema de Nunes da Silva a él ofrecido.

45 “Ao que vimos", O Neo-Socialista. Órgão da Liga da Mocidade do Porto, Porto, 1, 31 de janeiro de 1926, p. 1. Se trataba de una publicación "eventual".

46 "1 de maio", A União, Covilhã, 66, 5 de maio de 1927, p. 1.

47 Silva, Joaquim Palminha, "Evolução do Partido Socialista da I República ao 25 de abril de 1974", en Marques, Fernando Pereira (Coord.), O socialismo e o PS em Portugal, Lisboa, Âncora Editora, 2017, pp. $70-75$. 
que prestaron mayores servicios a la ilustre Sociedade de Instrução e Beneficência $A$ Voz do Operário (1889) y a su órgano de expresión, A Voz do Operário (1879), ambos vinculados a los obreros manipuladores de tabaco ${ }^{48}$, se silencia a Ernesto da Silva, que en vida había tenido con ellos las mejores relaciones ${ }^{49}$. Sí se reconoció la labor de Custódio Brás Pacheco, que había sido el inspirador de su periódico ${ }^{50}$, y la influencia de monárquicos como Augusto Fuchini y João Franco; republicanos como Sidónio Pais, Magalhães Lima, Angelina Vidal y Fernão Botto Machado, o el pedagogo Adolfo Coelho. Vinculados al PSP se citan únicamente los nombres del historiador Oliveira Martins, representante del socialismo de cátedra, y del militante José Fernandes Alves ${ }^{51}$. Además, la muerte de los supervivientes del socialismo histórico, como el mismo Fernandes Alves en 1931, Ladislau Batalha en 1939 — de quien documentamos una breve reseña biográfica en A Comuna, de Oporto, en 191952 - y Martins Santareno, acabó por sepultar en el olvido a todos estos líderes, excepción tal vez hecha a Fontana y Azedo Gneco, que al contrario de otros, sí se mantuvieron en el imaginario de los militantes. Para paliarlo, César Nogueira (1879-1973) se dispuso a recuperar la memoria histórica del socialismo portugués en los años inmediatos a la dictadura salazarista. Socialista él mismo, fue uno de los primeros historiadores de esta agrupación, tarea a la que se dedicó con coraje a lo largo de su vida. Con motivo del $1^{\circ}$ de mayo de 1932 publicó un Resumo histórico dos congressos e conferências do Partido Socialista Português (1871-1926) (Porto, Ed. da Revista Pensamento, s.d.), que ofrendó a los socialistas portugueses: "Em homenagem à memória dos militantes da obra socialista na Região Portuguesa (1871-1926) dedica com respeitosa veneração o autor". Dos años más tarde escribió un Esboço biográfico de Azedo Gneco (Lisboa, António Francisco Pereira, 1934) ${ }^{53}$, y en 1950 Antero de Quental. Esboço para a

48 La "Sociedade de Instrução e Beneficência A Voz do Operário" nació como un instrumento de apoyo al periódico A Voz do Operário, el órgano de la Associação de Classe dos Manipuladores de Tabaco, inicialmente como sociedad cooperativa. A partir de 1889 transformó su estatuto legal para abordar con mayor eficacia sus labores pedagógicas. El periódico A Voz do Operário se fundó en 1879 y sigue en activo en la actualidad. Sobre la historia de la Sociedade y su periódico hasta la proclmación de la República en 1910 vid., por ejemplo, los tres primeros capítulos de la monografía conmemorativa a cargo de Franco, Alberto, A Voz do Operário. Sociedade de Instrução e Beneficência..., cit., pp. 15-59.

49 El periódico A Voz do Operário notició elogiosamente el informe de cuentas referido a la celebración del $1^{\circ}$ de mayo de 1893, elaborado por Ernesto da Silva. En agradecimiento, el autor les dedicó un cuento que publicó en A Federação. Silva, Ernesto, “Á Voz do Operario", A Federação, Lisboa, 16, 22 de abril de 1894, p. 3; y Ruy, "Folhetim do jornal A Federação. Á ceia. (Á redacção da "Voz do Operario»). (Dialogo burguez)", ídem, n 40, 7 de outubro de 1894.

50 Franco, Alberto, A Voz do Operário..., op. cit., p. 30 y ss.

51 Santos, Raul Esteves dos, "Palavras pronunciadas no Salão de Festas de «A Voz do Operário»", Figuras gradas de A Voz do Operário, Lisboa, Ed. da Sociedade de Instrução e Beneficência A Voz do Operário, 1936.

52 Santareno, Martins, "Indicações biograficas", A Comuna, Porto, 7, 21 de maio de 1919, p. 2.

53 Según información en PORBASE, el buscador integrado de la red de bibliotecas en Portugal, formaba parte de una colección denominada Biblioteca do Grupo Editor O Protesto, pero no refiere conservación de ejemplares. Vid. http://porbase.bn.pt/ipac20/ipac.jsp?profile=porbase\&menu=search\&aspect=bas ic_search\&npp $=20 \& i p p=20 \& s p p=20 \&$ index $=$. TW\&term $=$ esbo $\% \mathrm{C} 3 \% \mathrm{~A} 7 \mathrm{o} \% 20 \mathrm{biogr} \% \mathrm{C} 3 \% \mathrm{~A} 1$ fico $\% 20$ \&oper $=$ AND\&index $=$.AW\&term $=$ nogueira 
sua biografia político-social (Porto, Imprensa Social, 1950), con prefacio de Câmara Reis (1885-1961), uno de los fundadores de la revista literaria Seara Nova (1921) —órgano del Grupo da Biblioteca Nacional ${ }^{54}$ _, aunque José Fontana continuará siendo el líder histórico que más atención ha merecido. En 1953 el mismo César Nogueira publicó José Fontana. A sua vida e a sua obra (Lisboa, Seara Nova, 1953), también prefaciado por Câmara Reis, un pequeño librito de apenas treinta y ocho páginas en el que el autor relata la relación de Fontana con la organización del movimiento obrero en Portugal, desde la creación de Fraternidade Operária, incluyendo testimonios y cartas del mismo Fontana, hasta su suicidio en 1876, con apenas treinta y seis años de edad, así como la posterior edificación de un monumento en el cementerio de los Prazeres.

Al margen de las publicaciones de César Nogueira, la figura de Fontana quedó momentáneamente olvidada, pero desde finales de la década de los años 60 del siglo XX, tal vez como un signo de los tiempos, marcados por el leve aperturismo que supuso la llegada al poder de Marcelo Caetano, comenzó una nueva recuperación de la memoria de los líderes históricos del socialismo portugués decimonónico por los militantes supervivientes del antiguo PSP a través de Portugal Socialista (1966-2004), el órgano de expresión de Ação Socialista Portuguesa ${ }^{55}$, y a partir de inicios de la década de 80 , también por historiadores profesionales. Entre los primeros, Fernando Piteira Santos se ocupó de Fontana en una breve nota titulada "José Fontana, militante do movimento operário português", que publicó en el histórico Diário de Notícias (22 de setembro de 1983). Ese mismo año el profesor Óscar Lopes abordaría el estudio de Antero de Quental. Tratándose del fundador histórico del PSP, las notas biográficas por diversos autores y en multitud de circunstancias fueron habituales en las décadas finales del siglo XIX y especialmente tras la proclamación de la Primera República (1910), pero Antero de Quental es también uno de los autores canónicos dentro de la historia de la literatura, y de ahí ese acercamiento en lo que constituye una de las escasas biografías publicadas sobre él: Antero de Quental. Vida e legado de uma utopia (Lisboa, Caminho, 1983). Sin embargo, quien continuó recibiendo la atención de los historiadores fue Fontana y así, partiendo del texto de César Nogueira, Maria Manuela Cruzeiro reconstruyó sus primeros años en su Suiza natal, así como sus orígenes familiares, que remontan a Italia y Francia, en Vida e acção de José Fontana (1990), publicado en la Fundação José Fontana, una institución dependiente del

54 De él fomaban parte intelectuales republicanos de prestigio: Jaime Cortesão, António Sérgio, Aquilino Ribeiro, Raúl Proença, Manuel Teixeira Gomes... De este grupo partió un intento de revitalización del movimiento socialista en la década de los años 20 del siglo XX.

55 "José de Sousa — destacado militante socialista", Portugal Socialista, 44, 4 de junio de 1975; G. A., "O camarada Augusto", ídem, 81, 4 de febrero de 1976, biografía de Augusto Dias da Silva; "Monteiro, Álvaro - Entrevista", Portugal Hoje, 13 de ocutubre de 1979; Nogueira, César, "Vultos operários cambreses: Luís Soares", Aveiro e o seu distrito, 20, 1975. Ação Socialista Portuguesa fue fundada en 1964 por Mário Soares, Manuel Tito de Morais y Francisco Ramos da Costa. Desapareció en 1973 para dar lugar al Partido Socialista. 
nuevo Partido Socialista $(1973)^{56}$. Unos años más tarde volvió sobre el biografiado en Um republicano chamado José Fontana (Lisboa, Fonte da Palavra e Associação Cedro, 2011).

Esta tríada de líderes: José Fontana, Antero de Quental y Eudóxio César Azedo Gneco, elucida bien sobre quiénes eran considerados los líderes más relevantes del socialismo portugués decimonónico por los militantes del siglo XX. César Nogueira en Notas para a história do socialismo em Portugal (vol I. 1871-1910; vol. II. 1895-1925) (Lisboa, Portugália Editora, 1964) añadió cuatro más en un apéndice a la obra: los ya citados José Correia Nobre França, Manuel Luiz de Figueiredo y Ernesto da Silva, además de Manuel José da Silva ${ }^{57}$. En 1986 Maria Filomena Mónica y Maria Goretti Matias se acercaron a la figura de uno de estos líderes olvidados e, incluso, desdeñados, Manuel Luiz de Figueiredo, rescatando su biografía y sus artículos en un texto hoy clásico para el estudio del socialismo portugués de finales del siglo XIX y con un título significativo: "Manuel Luís de Figueiredo, um socialista ignorado" 58 . No será hasta la llegada de la nueva centuria cuando el profesor António Ventura reivindique la acción de otro de estos líderes desconocidos en la actualidad, Ernesto da Silva. En una de las notas a Anarquistas, republicanos e socialistas em Portugal. As convergências possíveis (1892-1910), en referencia a este autor escribió: "Ernesto da Silva, desaparecido com apenas 35 anos, foi um dos mais destacados militantes socialistas portugueses, com uma obra escrita muito significativa e merecedora de um estudo aprofundado" ${ }^{59}$. Él mismo inició la recuperación del autor en el artículo "Ernesto da Silva e o socialismo" (2010), donde analiza uno de los aspectos más controvertidos de su vida y de su obra, sus supuestas simpatías anarquistas ${ }^{60}$. En la monografía antes citada, el profesor Ventura ya había calificado su pensamiento como "socialismo heterodoxo" 61 . Textos posteriores tratan de contribuir al análisis de su vida y su obra, que permanece inédita ${ }^{62}$. El gráfico José Correia Nobre França, autor de los

56 La Fundação José Fontana y la Fundação Antero de Quental — Centro de Estudos Municipais e de Ação Regional se fusionaron para dar lugar a la Fundação Res Publica, dependiente del Partido Socialista.

57 César Nogueira, "Apéndice”, Notas para a história do socialismo em Portugal, vol. I (1871-1910), Lisboa, Portugália Editora, 1964, pp. 329-340.

58 Mónica, Maria Filomena, y Matias, Maria Goretti, "Manuel Luís de Figueiredo, um socialista ignorado", Estudos e Documentos, Instituto de Ciências Sociais da Universidade de Lisboa, Lisboa, ed. do Instituto de Ciências Sociais da Universidade de Lisboa, 1986.

59 Ventura, António, Anarquistas, republicanos..., op. cit., nota 205, p. 263.

60 Ventura, António, "Ernesto da Silva e o socialismo”, en Leal, Ernesto Castro (Coord.), Republicanismo, socialismo, democracia, Lisboa, Centro de História da Faculdade de Letras da Universidade de Lisboa, 2010, pp. 169-182.

61 Ventura, António, Anarquistas, republicanos..., op. cit., p. 108.

62 Es a lo que nos hemos dedicado en los últimos años: "El Partido Socialista Portugués...”, op. cit., pp. 89-107; “Aproximación a la vida y a la obra de Ernesto da Silva”, cit., pp. 53-71; "Los orígenes del teatro socialista en Portugal: O Capital (1895), de Ernesto da Silva", Revista da Faculdade de Letras. História, IV série, vol. 7, 2, 2017, pp. 216-236; "Literatura alegórico-fantasista socialista", Revista de Estudos Literários, 9, 2019, pp. 183-198; "Ruptura y pervivencia de los estereotipos masculino y femenino en el cuento socialista portugués (1893-1901)”, Revista de Investigaciones Históricas. Época Moderna y 
primeros programas socialistas aprobados en 1877, 1878 y 1880, y el tejedor portuense Manuel José da Silva, miembro de la facción marxista de Gneco y fundador de la Casa do Povo Portuense, permanecen en la actualidad, como muchos otros nombres del socialismo portugués decimonónico, en el anonimato. La iniciativa más ambiciosa para la recuperación de esta memoria olvidada a cargo de militantes actuales quizá sea, junto a la de César Nogueira, la desarrollada por Joaquim Palminha Silva (1945-2015) en una obra "pionera", como la calificó su autor: Pequeno dicionário do movimento socialista português (Lisboa, Fundação José Fontana, 1989), que tiene la virtud de identificar a buena parte de todos estos socialistas portugueses de los siglos XIX y XX, además de permitir una aproximación documentada a su vida. Junto a este propósito, el autor se propuso historiar también las organizaciones políticas y las asociaciones socioeconómicas que permanecieron en la órbita del socialismo portugués. Además, incorporó una síntesis de acontecimientos o instituciones políticas nacionales e internacionales, así como de personalidades extranjeras relacionadas con el movimiento obrero y socialista portugués como único criterio ${ }^{63}$.

La alusión del autor a los socialistas del siglo XIX como "companheiros de jornada" evidencia un deseo de trascendencia del Partido Socialista nacido a finales del siglo XX con su partido hermano decimonónico. El PSP acabaría por desaparecer en 1934 tras la celebración en Coimbra de la IV Conferência Nacional Socialista (11 a 13 de marzo de 1933) y después de aprobar su último programa partidario, incapaz de sobrevivir a las exigencias organizativas que imponía la clandestinidad. Se mantuvo de forma nominal como Sección Portuguesa (SPIO) integrado en la Internacional Obrera y Socialista (19231951). En 1944 la SPIO favoreció, con mucha resistencia interna, su unificación con otros grupos socialistas surgidos en estos años, como União Socialista (US) (1944), llegando a firmar un acuerdo en $1948^{64}$. Estas tensiones procedían de una ruptura generacional entre los antiguos dirigentes y un grupo más joven defensor de una colaboración más estrecha con partidos de la órbita comunista, como el Partido Trabalhista Português (PTP) y el Partido Socialista Independente (PSI), llegando a formar en 1947 el Frente Socialista, al que se unirían depués el Partido Socialista Operário (PSO) y otros grupos socialistas independientes, pero el proyecto fracasaría. Por su parte, en julio de 1948 los militantes más antiguos de la SPIO intentaron una nueva alianza con la US, a la que se incorporaría Juventude Socialista Portuguesa (JSP), pero será suprimida un año más tarde, en julio de

Contemporánea, 39, 2019, pp. 517-542; “Os socialistas perante o infanticídio e o aborto", Revista de História da Sociedade e da Cultura, 19, 2019, pp. 297-316.

63 Silva, Joaquim Palminha, Pequeno dicionário do movimento socialista português, Lisboa, Fundação José Fontana, 1989, p. 7.

64 Susana Martins en Socialistas na oposicição ao Estado Novo (2005), afirma la disolución del grupo entre 1946 y 1947, aunque Nuno Miguel Santos data la firma del referido pacto en 1948. Vid. Santos, Nuno Miguel, "União Socialista: contribuição para o estudo de uma organização oposicionista de ideário socialista durante o salazarismo", en Marques, Fernando Pereira (Coord.), O socialismo e o PS..., op. cit., p. 88 , y nota 26 , p. 87. 
1949, para dar lugar a Aliança Socialista, de la que formaban parte otras organizaciones, especialmente el PTP, que fue, junto a la SPIO, los promotores de esta unión. El objetivo de todos estos movimientos fue siempre la reunificación del espacio socialista, de nuevo intentado, y malogrado, en agosto de 1949. Según José Magalhães Godinho, las tensiones dentro de la SPIO entre los socialistas "históricos" y los "nuevos" explican estos continuos fracasos, ya que fueron incapaces de llegar a un entendimiento. A principios de la década de los años 50 todavía se registra un último esfuerzo para proceder a la anhelada unificación partidaria. Hacia finales de 1952 e inicios de 1953 nacería un nuevo Frente Socialista, del que formaban parte US y JSP, junto a otras pequeñas agrupaciones, pero el proyecto fracasó nuevamente ${ }^{65}$.

A finales de la década de los años 50 surge, al margen de estas agrupaciones, pero también del Partido Comunista Portugués y de los grupos republicanos, liberales y democristianos que formaban la oposición al régimen salazarista, una sociedad a la que sus integrantes - Manuel Mendes, Francisco Ramos da Costa, Fernando Piteira Santos, Gustavo Roromenho, José Ribeiro dos Santos, Eurico Ferreira, José Magalhães Godinho, Francisco Mendes, Francisco Salgado Zenha, Catanho de Meneses y Mário Soaresdenominaron Resistência Republicana e Socialista, que propuso la candidatura de Jaime Cortesão a la presidencia de la República en $1958^{66}$. Para Mário Soares fue el instrumento que permitió definir claramente una opción política democrática bien diferenciada tanto a su derecha como a su izquierda, aunque sin poder crear lazos con la clase obrera, que permaneció fiel al PCP. En 1964 se transformó en Ação Socialista Portuguesa —rápidamente integrada en la Internacional Socialista — de la mano de Mário Soares, Manuel Tito de Morais y Francisco Ramos da Costa con el objetivo final de transformarla en una agrupación política ${ }^{67}$. El Partido Socialista, fundado finalmente en 1973, logró consolidarse, no sin muchas dificultades, como partido oposicionista al régimen salazarista disputándole espacio al bien organizado - y financiado - Partido Comunista Portugués, liderado por Álvaro Cunhal, aunque solo logró la hegemonía después del 25 de abril.

\section{LOS POLÍTICOS SOCIALISTAS PROFESIONALES: DE AUGUSTO DIAS DA SILVA A MÁRIO SOARES E JORGE SAMPAIO}

En los años previos a la proclamación de la República el PSP es un partido pequeño que paulatinamente se va consolidando como órgano de referencia de las masas obreras asalariadas aunque, paradójicamente, durante el período republicano su influencia se debilita. Entre las causas que explican esta fragilidad suelen señalarse las tensiones internas, el desencanto ante la acción de gobierno del Partido Republicano Português y, sobre todo,

65 Santos, Nuno Miguel, "União Socialista...", op. cit., pp. 88-90.

66 Soares, Mário, Um político assume-se. Ensaio autobiográfico, político e ideológico, Lisboa, Círculo de Leitores e Temas \& Debates, 201, p. 77 y ss.

67 Castaño, David, “Mário Soares e a revolução, Lisboa, D. Quixote, 2013, pp. 58 y 111. 
la creciente influencia del anarquismo entre las organizaciones sindicales ${ }^{68}$. Su mayor éxito vino, sin duda, de su llegada a la gestión del Estado con el nombramiento en 1919 de Augusto Dias da Silva (1887-1828) como Ministro do Trabalho en los gobiernos de José Relvas (27 de enero a 30 de marzo) y Domingos Pereira (30 de marzo a 6 de mayo), motivo por el cual Martins Santareno le dedicó una semblanza en 1919 en A Comuna, el periódico del Grupo de Propaganda Social ${ }^{69}$; y de Ramada Curto, diputado desde 1911, que después de militar en el Partido Democrático - la denominación del Partido Republicano Português (1883) después de 1910—, se afilió al Partido Socialista Português y fue nombrado Ministro das Finanças en 1919 (30 de marzo a 29 de junio), y de Trabajo en 1920 ( 21 de enero a 8 de marzo) en los gobiernos de Domingos Pereira ${ }^{70}$. En 2014 fue escogido por el profesor Luís Farinha para formar parte de una colección denominada "Parlamentares da I República", destinada a recomponer el régimen republicano a través del análisis de figuras representativas de sus principales familias políticas. No estamos en presencia, por lo tanto, de una biografía en sentido estricto, "ou a sê-lo, pretende-se confinada à sua vida pública" "71, explica su autor, esto es, dejando de lado su intensa actividad como dramaturgo que, no obstante, aparece referenciada en el apéndice documental que completa la obra. El nombramiento de ambos líderes evidencia una transformación dentro del PSP hacia la profesionalización política de la mano de militantes procedentes de las clases liberales —abogados, industriales o ingenieros—, que a finales de la centuria completarán Mário Soares y Jorge Sampaio, en abierto contraste con los líderes del siglo XIX, que aunque intelectualizados, son de extracción obrera y, por lo tanto, sin una formación académica que los preparase para el acceso al poder. Radicaba en esta circunstancia la desconfianza de uno de estos líderes, Ernesto da Silva, compositor de tipógrafo de profesión, en relación a las posibilidades que el PSP tenía de acceder a las altas magistraturas del Estado a finales del Ochocientos. Lo expuso ya en 1893 en Proletários e Burguezes, y de nuevo en 1898 recordando los objetivos del fallido intento de publicación de un periódico socialista: "Base $3 .^{\mathrm{a}}$ — Defenderá todas as reformas democraticas, combaterá sem compromissos contra as instituições monarquicas: e ficará na opposição, em prol do socialismo, logo que o partido republicano seja poder"72.

68 Silva, Joaquim Palminha, "Evolução do Partido Socialista da I República ao 25 de abril de 1974", en Marques, Fernando Pereira (Coord.), O socialismo e o PS..., op. cit., p. 70; Ramos, Rui, "As «carrapatas» de Afonso Costa" y “Os Anarquistas”, en Mattoso, José (Dir.), História de Portugal. Sexto Volume. A Segunda Fundação (1890-1926), Lisboa, Editorial Estampa, 1994, pp. 467-471, y 553-555, respectivamente.

69 Santareno, Martins, "O Ministro do Trabalho", A Comuna. Bi-semanario socialista, Porto, 2, 3 de maio de 1919, p. 1. Joaquim Palminha Silva en Pequeno dicionário..., cit., p. 45, documenta referencias bibliográficas en O Combate (20 de abril de 1919) y O Protesto en 1922.

70 Silva, Joaquim Palminha, Pequeno dicionário..., op. cit., pp. 38-39.

71 Farinha, Luís, Ramada Curto. Republicano, socialista, laico, Lisboa, Assembleia da República, 2014, pp. 15 y 16.

72 Silva, Ernesto, "Carta-Artigo", A Obra, Lisboa, n 173, 8 de maio de 1898, p. 1; y ídem, Proletários e Burguezes, Lisboa, Instituto Geral das Artes Graphicas, 1893, p. 13. 
No será hasta el fin del Estado Novo y el inicio de la transición a la democracia a partir de 1974 cuando los socialistas regresen al gobierno a través de Mário Soares (19242017), que en 1974 forma parte, junto a Álvaro Cunhal (1913-2005), el líder del PCP, del $\mathrm{I}^{\text {er }}$ Gobierno Provisional (16 de mayo) como Ministro de Asuntos Exteriores. A partir de entonces, ambos políticos fueron objeto de libros de memorias y biografías: el líder comunista en las obras de José Pacheco Pereira, Álvaro Cunhal, uma biografia política, en cuatro volúmenes: Daniel, o jovem revolucionário (1913-1941), Duarte, o dirigente clandestino (1941-1949), O prisioneiro (1949-1960) y O secretário-geral (1960-1968) (Lisboa, Temas e Debates, 1999-2015); y de Carlos Brito en Álvaro Cunhal, sete fólegos de combatente. Memórias (Lisboa, Edições Nelson de Matos, 2010); y Mário Soares en las entrevistas concedidas a Maria João Avillez desde mediados de la década de los años 90 del siglo XX: Soares: ditadura e revolução (Lisboa, Público, 1995; Círculo de Leitores, 1996), y Soares: democracia (Lisboa, Círculo de Leitores, 1996). Desde finales del siglo XX y principios del siglo XXI se han publicado biografías que, dado el tiempo transcurrido, presentan mayor perspectiva histórica. La de J. P. Castanheira, Jorge Sampaio, uma biografia (Lisboa, Edições Nelson e Porto Editora, 2012), está dedicada a quien fuera líder del PS entre 1989 y 1991; y otra a Mário Soares bajo el título Mário Soares e a revolução (Lisboa, D. Quixote, 2013), de la autoría de David Castaño. Esta nueva aportación se inscribe dentro de una tendencia clásica dentro del género biográfico y de la historia política: la de servir de análisis de una época, de un período histórico, en este caso concreto, con el objetivo de, en palabras de su autor, "identificar os momentos em que as opções tomadas por um indivíduo, mesmo que em nome de um grupo mais vasto, contribuíram para a condução do processo de transição numa direção em detrimento de outras alternativas que então se colocavam"73.

\section{AUSENCIAS PERTINACES. EL OLVIDO DE LAS LÍDERES SOCIALISTAS FEMENINAS}

Entre todas estas referencias surge una evidencia: la aparente inexistencia de líderes femeninas en la historia del socialismo portugués, pues ninguna de ellas parece haber recibido homenaje público de los militantes. Joaquim Palminha Silva en su Pequeno dicionário do movimento socialista português apenas individualiza a Florinda Bella (†1904), una de las fundadoras de la Associação das Costureiras, y a Alexandrina Soares Homem ( $\dagger$ 1931), integrante de la União das Mulheres Socialistas de Portugal ${ }^{74}$. Sin embargo, sabemos de varias mujeres con influencia en los medios obreros desde la fundación del Partido a finales del siglo XIX, especialmente en las profesiones dominadas por ellas, como las lavanderas, las costureras y aparadoras, y las comadronas, las primeras en constituir sus

73 Castaño, David, "Introdução”, Mário Soares e a revolução..., op. cit., p. 14.

74 Silva, Joaquim Palminha, Pequeno dicionário..., op. cit., pp. 30 y 12, respectivamente. 
propias asociaciones de clase ${ }^{75}$. Es el caso de Florinda Bella, dirigente de la Associação de Classe das Costureiras e Ajuntadeiras, y especialmente Margarida Marques, cuya firma descubrimos en periódicos como A Federação o O Tecido, en artículos en defensa de sus intereses. En junio de 1897 se fundaba en Lisboa la Federação Feminina Socialista de la que formaban parte la propia Margarida Marques, Margarida Clotilde Ferreira, Maria da Encarnação, Mathilde de Jesus Pereira, Clotilde Garcez, Florinda Bella, Maria Rosa, Julia Rosa da Silva y Elvira Monteiro ${ }^{76}$. Ya durante los años de la República sabemos de la fundación de la União das Mulheres Socialistas en 1912, que en ese momento cuenta con noventa y una afiliadas, entre ellas, Matilde Simões, Alexandrina Homem, Eugénia Maia, Mariana Fernandes Alves, Amália Pereira y Margarida Marques ${ }^{77}$. Ninguna de ellas ha merecido hasta ahora la atención de los historiadores.

\section{A MODO DE CONCLUSIÓN. LA HISTORIOGRAFÍA OBRERA EN PORTUGAL (1933-2020)}

Lo expuesto anteriormente muestra que faltan estudios sobre la divulgación de las ideas socialistas, de las agrupaciones partidarias, y de los líderes obreros que las defendieron. Por lo que respecta al tema que nos ocupa, la escasez de biografías de los líderes locales es una consecuencia más de este déficit historiográfico. En general, el estudio del movimiento obrero, y en concreto, de la difusión del pensamiento socialista desde el último cuarto del siglo XIX hasta la institucionalización del Estado Novo, fue obra de los militantes socialistas, y en particular, de la exclusiva iniciativa de su principal historiador, César Nogueira, hasta apenas unos años antes de su fallecimiento en 1973. La interrupción de su trabajo enlaza con el nacimiento de una historiografía obrera científica en los años finales de la dictadura salazarista a cargo de historiadores profesionales, muchos de ellos militantes de los partidos de tradición obrera recientemente reconocidos, como una respuesta académica ante las diversas dificultades de análisis derivadas de un uso instrumentalista de la Historia por la dictadura, de las trabas impuestas para el acceso a la documentación para el estudio de temas que podían resultar incómodos para el régimen político y, en última instancia, de servicio a la recién recuperada democracia en Portugal, entre otras causas. Los estudios aparecidos desde inicios de la década de los años 70 hasta inicios de los años 90 del siglo XX pueden englobarse en tres grandes ejes temáticos: primero, la recuperación de las fuentes documentales, con especial realce para la prensa obrera, elaborando los primeros catálogos de periódicos. Son los trabajos de César de

75 Las mujeres integrantes de estas asociaciones participaron como delegadas al Congresso das Associações de Clase celebrado en Lisboa en 1897. Fonseca, Carlos da, História do movimento operário e das ideias socialistas em Portugal. IV. Greves e agitações operárias ( ${ }^{a}$ parte), Lisboa, Publicações Europa-América, s.d., pp. 282-283.

76 “Centro Socialista do Anjos", O Tecido, Lisboa, n 128, 27 de junho de 1897, p. 3.

77 Silva, Joaquim Palminha, Pequeno dicionário..., op. cit., p. 241. 
Oliveira, Vítor de Sá o Maria Filomena Mónica ${ }^{78}$. En segundo lugar, abordando el estudio de las agrupaciones obreras profesionales, de nuevo a cargo de Maria Filomena Mónica, Vasco Pulido Valente o José Barreto ${ }^{79}$; finalmente, fijando la historia del Partido Socialista Portugués desde su fundación en 1875 hasta su desaparición con la instauración del Estado Novo, encuadrándolo dentro del desarrollo del movimiento obrero en Portugal, de la autoría de Carlos da Fonseca, Maria Filomena Mónica, José Pacheco Pereira, Maria Goretti Matias, João Freire, Fernando Catroga, Vasco Pulido Valente o Joel Serrão, entre otros ${ }^{80}$. Muchos de estos trabajos vieron la luz en revistas nacidas acompañando el desarrollo de los estudios de historia social, como Análise Social, vinculada al Instituto de Ciências Sociais de la Universidad de Lisboa. Desde entonces, y hasta inicios de la nueva centuria, el estudio del movimiento obrero decae entre los historiadores profesionales, que recupera algo de pulso a partir de 2000 con los trabajos del profesor António Ventura $^{81}$ y la presentación de algunas tesis académicas que recontruyen la historia del movimiento obrero abordando cuestiones sectoriales, como la prensa o sus expresiones culturales, especialmente en el ámbito de la literatura ${ }^{82}$.

78 Oliveira, César, Antologia da Imprensa Operária Portuguesa, UGT-União Geral de Trabalhadores e Perspectivas \& Realidades, Artes Gráficas Ld a , Marzo, 1984; ídem, "Imprensa operária no Portugal oitocentista”, Análise Social, 39, 1973; Sá, Vítor de, Roteiro da imprensa operária e sindical, 1836-1986, Lisboa, ed. Caminho, 1991; Mónica, Maria Filomena y, Matos, Luís Salgado, "Inventário da imprensa operária portuguesa (1834-1934)”, Análise Social, 67-68-69, 1981, pp. 1013-1078; Mónica, Maria Filomena, A formação da classe operária portuguesa. Antologia da Imprensa Operária (1850-1934), Lisboa, Fundação Calouste Gulbenkian, s.d.

79 Mónica, Maria Filomena, "Indústria e democracia: os operários metalúrgicos de Lisboa (1880-1934)", Análise Social, 72-73-74, 1982; ídem, "Negócios e política: os tabacos (1800-1890)”, Análise Social, 116-117, 1992; ídem, "Poder e saber: os vidreiros da Marinha Grande”, Análise Social, 67-68-69, 1981; ídem, "Uma aristocracia operária: os chapeleiros (1870-1914)", Análise Social, 60, 1979; Valente, Vasco Pulido, "Os conserveiros de Setúbal", Análise Social, 67-68-69, 1981; Barreto, José, "Os tipógrafos e o despontar da contratação colectiva em Portugal” (I) y (II), Análise Social, vol. XVII (66), 1981-2º pp. 253-291; y vol. XVIII (70), 1982-1; Barreto, José, "Puro e duro: as memórias de um operário comunista da construcção civil”, Análise Social, 80, 1984, pp. 129-145.

80 Oliveira, César, O Operariado e a República Democrática (1910-1914), Lisboa, 8 a ed. Seara Nova, 1974; ídem, "Os limites e a ambiguidade: o movimento operário português durante a guerra de 19141918”, Análise Social, 20 (80), 1984; Mónica, Maria Filomena, O movimento socialista em Portugal (1875-1934), cit.; Pereira, José Pacheco, “A origem do movimento operário no Porto: as associações mutualistas (1850-70)”, Análise Social, 65, 1981; Mónica, Maria Filomena, y Matias, Maria Goretti, "Manuel Luís de Figueiredo, um socialista ignorado", Estudos e Documentos, Lisboa, ed. do Instituto de Ciências Sociais da Universidade de Lisboa, 1986; Freire, João, Anarquistas e operários. Ideologia, ofícios e práticas sociais: o anarquismo e o operariado em Portugal, 1900-1940, Porto, ed. Afrontamento, 1992; Valente, Vasco Pulido, "Revoluções: A «República Velha». (Ensaio de interpretação política)", Análise Social, 115, 1992; Serrão, Joel, Do sebastianismo ao socialismo, Lisboa, ed. Livros Horizonte, 1973.

81 Ventura, António, Anarquistas, republicanos... cit.; ídem, "Ernesto da Silva e o socialismo", op. cit., pp. 169-182.

82 Castro, Maria João de Abreu Mena Guimarães e, O Operário (1879-1882) e o movimento socialista no Porto, Dissertação de Mestrado em História Contemporânea, apresentado à Faculdade de Letras da Universidade do Porto, Porto, 1999; Santos, Licínio Manuel Moreira dos, "Cultura e lazer operários em Gaia, entre o final da Monarquia e o início da República (1893-1914)”, tesis de Mestrado en História 
En los último años, el interés por la historia del socialismo en Portugal ha recuperado interés entre los investigadores, que han organizado su estudio entorno a dos ejes temáticos. El primero de ellos aborda la acción política del PS a través de la biografía de sus líderes, que han llegado a la más alta magistratura del Estado, su jefatura. Estas monografías avanzan en la historiografía del movimiento socialista al regresar, paradójicamente, a una tendencia clásica que hacía de las individualidades políticas el objeto de su estudio, a la historia política. Con ellas, y a través de ellas, el historiador podía ofrecer el marco de análisis de la época, como hemos apuntado al referirnos a las biografías de Mário Soares y Jorge Sampaio ${ }^{83}$. Paralelamente, del segundo eje temático es ejemplo el volúmen coordinado por Fernando Pereira Marques O socialismo e o PS em Portugal (2017), que busca "inserir o socialismo do presente na sua história mais do que centenária" ${ }^{4}$. Esto es, se trata de abordar de nuevo la historia del movimiento socialista en Portugal analizando la difusión y consolidación de las ideas socialistas desde su nacimiento a mediados del siglo XIX hasta el siglo XXI y, por lo tanto, integrando sus dos organizaciones partidarias: el PSP, surgido en 1875, y el PS, en 1973, dentro de una única corriente de pensamiento y acción. Aunque parece estar dotada de algún consenso la idea de que los socialistas que fundaron el PS procedían tanto de las filas republicanas - Mário Soares y Manuel Tito de Morais son hijos, respectivamente, de João Lopes Soares, Ministro das Colónias en el gobierno de Domingos Leite Pereira en 1919, y de Tito Augusto de Morais, Ministro da Marinha en el gobierno de José Relvas en 1919, ambos militantes del Partido Republicano Português (o Partido Democrático)—, como de las comunistas, lo cierto es que nada hacer pensar ni en una continuación del antiguo PRP ni en una escisión del PCP o de las filas anarcosindicalistas, abandonando el radicalismo para optar por posiciones más moderadas ${ }^{85}$. Más bien, y a tenor de lo descrito en los estudios citados a lo largo de este trabajo, parece desprenderse la idea de una cierta indefinición ideológica inicial por parte de los futuros líderes del PS que tenía como elemento común su oposición al régimen salazarista. Con los años, esta indefinición ideológica se iría clarificando progresivamente. Deseosos de proceder al combate desde una militancia activa, pasarían a formar parte de

Contemporânea, Faculdade de Letras da Universidade do Porto, 2014; Santos, Licínio, “As «Escolas Operárias» em Vila Nova de Gaia”, en Ribeiro, Cláudia Pinto, y Araújo, Francisco Miguel, História da educação em Vila Nova de Gaia, Porto, CITCEM - Centro de Investigação Transdisciplinar "Cultura, Espaço e Memória”, 2017; Peralta García, Beatriz, La cultura obrera en Portugal. Teatro y socialismo durante la Primera República (1910-1926), Mérida, Junta de Extremadura, 2009; ídem, "Poesía y política en la prensa obrera. Las «Carapuças d'O Socialista»", AA. VV., Relaciones lingüísticas y literarias entre Portugal y España desde inicios del siglo XIX hasta la actualidad, Salamanca, Universidad de Salamanca, 2007, pp. 269-279; ídem, "Literatura y movimiento obrero en Portugal: la cultura política del socialismo en su teatro", Espacio. Tiempo y Forma, Historia contemporánea, t. 23, 2010, pp. 37-54; ídem, "E1 Partido Socialista Portugués...”, op. cit., pp. 89-107; ídem, "Los orígenes del teatro socialista...”, op. cit. pp. 216-236; ídem, “Literatura alegórico-fantasista socialista”, op. cit., pp. 183-198.

85 Por ejemplo, Castaño, David, Mário Soares e a revolução..., op. cit., p. 77. 
las organizaciones clandestinas mejor organizadas. Especialmente relevante es el caso de Mário Soares, que abandonó rápidamente el PCP y se autodefinió "socialista” ya en 1949, con apenas veinticuatro años, aunque no será hasta finales de la década de 50 que "fiquei, definitivamente, afastado do comunismo (da ideologia e do partido)”. Años después calificaría de "travessia do deserto" este período de su vida, que tuvo duras consecuencias a nivel personal ${ }^{86}$. Por el camino se quedaron amigos de juventud y compañeros, y aún habría de notar la renuncia y disconformidad de otros con la línea seguida por el Partido, fuertemente marcado incluso desde la fundación de AS por la personalidad de su líder, como los casos de Manuel Mendes y Piteira Santos, que acabarán abandonando la organización tras la fundación de AS; Manuel Serra, que después de perder el I ${ }^{\text {er }}$ Congreso en 1974 fundaría Frente Socialista Portuguesa (1975); o Salgado Zenha en 1981, que se alejó del partido que había ayudado a fundar cuando la mayoría del PS decidió votar en la Assembleia da República a favor de la revisión del texto constitucional ${ }^{87}$. El rejuvenecimiento historiográfico al que antes aludíamos debería abordar no solo estas cuestiones sino también el estudio de los líderes del siglo XIX, susceptibles de ser analizados a través de su vida y de sus obras, que se mantienen inéditas, dispersas sobre todo en la prensa, como los artículos de opinión y las obras literarias, sin olvidar las aportaciones de las mujeres socialistas.

86 Soares, Mário, Um político assume-se..., op. cit., pp. 54-55, 75, y 59, respectivamente.

87 Ídem, íbidem, pp. 111, 232-233, y 329-330, respectivamente. 


\section{BIBLIOGRAFÍA}

Alférez Sánchez, María (2019), "La Vida de Quevedo de Pablo de Tarsia: un modelo excepcional en la producción biográfica del Siglo de Oro", Revista de Historiografía, 30, pp. 225-244.

Barreto, José (1981-1982), "Os tipógrafos e o despontar da contratação colectiva em Portugal” (I) y (II), Análise Social, vol. XVII (66), 1981-2º, pp. 253-291; y vol. XVIII (70), 1982-1 ${ }^{\mathrm{o}}$;

Barreto, José (1984), "Puro e duro: as memórias de um operário comunista da construcção civil”, Análise Social, 80, 1984, pp. 129-145.

Bonifácio, Maria Fátima (2007), "Biografia e conhecimento histórico”, Estudos de história contemporânea de Portugal, Lisboa, ICS, 2007.

Castaño, David (2013), Mário Soares e a revolução. Lisboa, D. Quixote.

Castro, Maria João de Abreu Mena Guimarães e (1999), O Operário (1879-1882) e o movimento socialista no Porto. Dissertação de Mestrado em História Contemporânea, apresentado à Faculdade de Letras da Universidade do Porto, Porto.

Catroga, Fernando (1989), "Os primórdios do 1. ' de maio em Portugal. Festa, luto, luta", Revista de História das Ideias, 11, 1989, pp. 445-500.

Farinha, Luís (2014), Ramada Curto. Republicano, socialista, laico. Lisboa, Assembleia da República.

Fonseca, Carlos da (s.d.), História do movimento operário e das ideias socialistas em Portugal. IV. Greves e agitações operárias (I ${ }^{a}$ parte). Lisboa, Publicações EuropaAmérica.

Freire, João (1992), Anarquistas e operários. Ideologia, ofícios e práticas sociais: o anarquismo e o operariado em Portugal, 1900-1940. Porto, ed. Afrontamento.

Lázaro, João (2019), "O Centro Promotor dos Melhoramentos das Classes Laboriosas. Integração e rutura na sociedade liberal portuguesa (1852-1873)", Revista Portuguesa de História, t. L., pp. 67-85.

Marques, Fernando Pereira (Coord.) (2017), O socialismo e o PS em Portugal. Lisboa, Âncora Editora.

Mattoso, José (Dir.) (1994), História de Portugal. Sexto Volume. A Segunda Fundação (1890-1926). Lisboa, Editorial Estampa.

Mónica, Maria Filomena (1979), “Uma aristocracia operária: os chapeleiros (18701914)", Análise Social, 60.

Mónica, Maria Filomena (1981), "Poder e saber: os vidreiros da Marinha Grande", Análise Social, 67-68-69.

Mónica, Maria Filomena (1982), "Indústria e democracia: os operários metalúrgicos de Lisboa (1880-1934)”, Análise Social, 72-73-74.

Mónica, Maria Filomena (1985), O movimento socialista em Portugal (1875-1934). Lisboa, Imprensa Nacional-Casa da Moeda.

Mónica, Maria Filomena (1992), "Negócios e política: os tabacos (1800-1890)”, Análise Social, 116-117. 
Mónica, Maria Filomena (s.d.), A formação da classe operária portuguesa. Antologia da Imprensa Operária (1850-1934). Lisboa, Fundação Calouste Gulbenkian, s.d.

Mónica, Maria Filomena y, Matos, Luís Salgado (1981), "Inventário da imprensa operária portuguesa (1834-1934)”, Análise Social, 67-68-69, pp. 1013-1078;

Mónica, Maria Filomena, y Matias, Maria Goretti (1986), "Manuel Luís de Figueiredo, um socialista ignorado", Estudos e Documentos, Instituto de Ciências Sociais da Universidade de Lisboa, Lisboa, ed. do Instituto de Ciências Sociais da Universidade de Lisboa.

Morales Moya, Antonio (1993), "Biografía y narración en la Historiografía actual”, en: Sánchez Nistal, José María, y otros, Problemas actuales de la Historia. $3^{\text {as }}$ Jornadas de Estudios Históricos, Salamanca, Universidad de Salamanca.

Nogueira, César (1964), Notas para a história do socialismo em Portugal, vol. I (18711910). Lisboa, Portugália Editora.

Oliveira, César (1973), "Imprensa operária no Portugal oitocentista”, Análise Social, 39.

Oliveira, César (1974), O Operariado e a República Democrática (1910-1914). Lisboa, $8^{\mathrm{a}}$ ed. Seara Nova.

Oliveira, César (1984), “Os limites e a ambiguidade: o movimento operário português durante a guerra de 1914-1918”, Análise Social, 20 (80).

Oliveira, César (1984), Antologia da Imprensa Operária Portuguesa. UGT-União Geral de Trabalhadores e Perspectivas \& Realidades, Artes Gráficas Ld ${ }^{\mathrm{a}}$.

Oliveira, César de (s.d.), 13 de cartas de Portugal para Engels e Marx. Recolha, prefácio e notas de César de Oliveira. Lisboa, Iniciativas Editoriais.

Peralta García, Beatriz (2007), "Poesía y política en la prensa obrera. Las «Carapuças d'O Socialista»", en: AA. VV., Relaciones lingüísticas y literarias entre Portugal y España desde inicios del siglo XIX hasta la actualidad, Salamanca, Universidad de Salamanca, pp. 269-279;

Peralta García, Beatriz (2009), La cultura obrera en Portugal. Teatro y socialismo durante la Primera República (1910-1926). Mérida, Junta de Extremadura.

Peralta García, Beatriz (2010), "Literatura y movimiento obrero en Portugal: la cultura política del socialismo en su teatro", Espacio. Tiempo y Forma, Historia contemporánea, t. 23, pp. 37-54.

Peralta García, Beatriz (2017), "Aproximación a la vida y a la obra de Ernesto da Silva", Historia Social, 89, pp. 53-71.

Peralta García, Beatriz (2017), "El Partido Socialista Portugués y la literatura de combate. La obra literaria de Ernesto da Silva", Revista Historia Autónoma, 11, pp. 114-124.

Peralta García, Beatriz (2017), "Los orígenes del teatro socialista en Portugal: O Capital (1895), de Ernesto da Silva”, Revista da Faculdade de Letras. História, IV série, vol. 7, 2, pp. 216-236.

Peralta García, Beatriz (2019), "Literatura alegórico-fantasista socialista”, Revista de Estudos Literários, 9, pp. 183-198.

Peralta García, Beatriz (2019), "Os socialistas perante o infanticídio e o aborto", Revista de História da Sociedade e da Cultura, 19, pp. 297-316. 
Peralta García, Beatriz (2019), "Ruptura y pervivencia de los estereotipos masculino y femenino en el cuento socialista portugués (1893-1901)”, Revista de Investigaciones Históricas. Época Moderna y Contemporánea, 39, pp. 517-542.

Pereira, José Pacheco (1981), “A origem do movimento operário no Porto: as associações mutualistas (1850-70)”, Análise Social, 65.

Queiroz, Eça de (2008), Correspondência. Volume II, organização e anotações de A. Campos Matos, s.l., Caminho.

Quental, Antero de [1871] (2008), Causas da decadência dos povos peninsulares nos três últimos séculos. Lisboa, Tinta-da-China.

Sá, Vítor de (1991), Roteiro da imprensa operária e sindical, 1836-1986. Lisboa, ed. Caminho.

Santos, Licínio (2017), “As «Escolas Operárias» em Vila Nova de Gaia”, en: Ribeiro, Cláudia Pinto, y Araújo, Francisco Miguel, História da educação em Vila Nova de Gaia, Porto, CITCEM — Centro de Investigação Transdisciplinar "Cultura, Espaço e Memória".

Santos, Licínio Manuel Moreira dos (2014), Cultura e lazer operários em Gaia, entre o final da Monarquia e o início da República (1893-1914). Dissertação de Mestrado en História Contemporânea, Faculdade de Letras da Universidade do Porto, Porto.

Serrão, Joel (1973), Do sebastianismo ao socialismo. Lisboa, ed. Livros Horizonte.

Silva, Joaquim Palminha (1989), Pequeno dicionário do movimento socialista português. Lisboa, Fundação José Fontana, 1989.

Soares, Mário (2011), Um político assume-se. Ensaio autobiográfico, político e ideológico. Lisboa, Círculo de Leitores e Temas \& Debates.

Valente, Vasco Pulido (1981), "Os conserveiros de Setúbal”, Análise Social, 67-68-69.

Valente, Vasco Pulido (1992), "Revoluções: A «República Velha». (Ensaio de interpretação política)", Análise Social, 115.

Ventura, António (2000), Anarquistas, republicanos e socialistas em Portugal. As convegências possíveis (1892-1910). Lisboa, Edições Cosmos.

Ventura, António (2010), "Ernesto da Silva e o socialismo", en: Leal, Ernesto Castro (Coord.), Republicanismo, socialismo, democracia. Lisboa, Centro de História da Faculdade de Letras da Universidade de Lisboa, pp. 169-182. 